\title{
Changes in the physicochemical characteristics and antioxidant activity of barley during germination using different pre-treatment methods
}

\author{
Ji-Hye Park, Min-Jung Kang, Jae-Ran Kang, Jung-Hye Shin \\ Namhae Garlic Research Institute, Namhae 52430, Korea
}

\section{전처리 방법을 달리한 보리의 발아 중 이화학적 특성 및 항산화 활성}

\author{
박지혜 · 강민정 · 강재란 · 신정혜* \\ (재) 남해마늘연구소
}

\begin{abstract}
In this study, we established the pre-treatment conditions that could increase the $\gamma$-aminobutyric acid (GABA) content during barley germination. In the process, three different barley samples were prepared, which differed in the pre-treatedment processes. The specimens were stored at $50^{\circ} \mathrm{C}$ for $1 \mathrm{~h}$ after being kept in water at room temperature for $4 \mathrm{~h}$ (HKW sample), kept in sufficient water for $4 \mathrm{~h}$ (KW sample), or left untreated (CO sample). After the pre-treatment, the barely samples were germinated for $35 \mathrm{~h}$. A sample was taken from each batch in 5-h intervals, extracted with water, and physicochemical characteristics and radical scavenging activity were measured. As a result, we found that the contents of phenolic compounds $(18.02-30.63 \mathrm{mg} / 100 \mathrm{~g})$ and flavonoids $(1.87-4.63 \mathrm{mg} / 100 \mathrm{~g})$ were higher in HKW, showing similar trends. Also the GABA contents in the HKW and KW samples were higher than that in the CO sample. Furthermore, the radical scavenging activities of DPPH and ABTS were the highest in the HKW sample, having values in the ranges of 58.49-77.40\% and 54.57-88.10\%, respectively. All in all, we found that in order to increase the antioxidative activity and GABA content of the barley samples, it would be suitable to pre-treatment the specimens after the post-immersion heat treatment. In addition, pre-treating the KW samples is appropriate only after immersion time. Lastly, the optimum germination time of the batches was found to be $20-25 \mathrm{~h}$.
\end{abstract}

Key words : GABA, barley, pre-treatment, germination, antioxidant

\section{서 론}

최근 건강에 대한 인식이 높아짐에 따라 식생활이 건강 에 미치는 영향에 대한 관심 또한 높아지면서 여러 형태의 건강식품에 대한 수요가 증가하고 있는데, 이러한 측면에 서 기존의 주식 원료인 쌀이나 보리, 밀을 발아시켜 건강 기능성을 향상시키고 건강식품으로 전환하고자 하는 연구 가 다수 진행되고 있다(1).

*Corresponding author. E-mail : whanbee@daum.net Phone : 82-55-860-8947, Fax : 82-55-860-8960

Received 13 December 2017; Revised 25 February 2018; Accepted 11 May 2018.

Copyright (c) The Korean Society of Food Preservation. All rights reserved.
보리(Hordeum vulgare)는 세계적으로 소비가 많은 곡물 중 하나로서 단백질, 지방질 및 무기질 등의 영양성분을 고르게 함유하여 영양학적으로는 매우 우수하나 phytic acid와 전분의 강한 결합구조로 인하여 식감이 떨어지는 단점이 있다(2-6). 보리를 발아시키면 phytic acid와 전분이 분해되어 식감과 소화성을 개선할 수 있을 뿐만 아니라 amylase, protease, phytase 및 $\beta$-glucanase와 같은 다양한 효소들에 의해서 8 -aminobutyric acid(GABA), 아미노산, arabinoxylan, 비타민 $\mathrm{E}$ 등 다양한 생리활성 물질들의 함량 이 증가한다(7). 또한, 발아 시작과 함께 종자 내부에 저장된 단백질이 protease에 의해 분해되고 올리고당이 저분자로 가수분해 되면서 당과 단백질의 소화를 증대시켜 영양소의 이용율을 효과적으로 증가시키므로(8) 발아는 곡물의 기능 성을 증가시키는 가공처리법이다(9). 
식물 종자가 발아하면 씨눈과 배젖에 있는 비활성 상태 의 DNA 유전정보가 활성화 되고 각종 효소의 활성 및 영양 소가 증가되어 최대의 영양상태가 갖추어지게 된다(10). 발아된 벼 추출물은 여러 가지 암세포주 증식을 억제하며 $(11,12)$ 발아보리의 당단백질 추출물은 대식세포를 자극하 여 면역매개물질 생성을 통해 면역증진 효과를 나타낸다 (13). 발아 검은 쌀로부터 분리한 올리고펩타이드는 피부 탄력개선에 효과가 있으며(14), 발아녹두 추출물은 항염증 활성이 증가되어 화장품의 자극 완화제와 항염증 소재로 응용이 제안되고 있다(15). 즉 조, 기장, 수수(16), 메밀(17), 들깨(18), 대두(19) 등의 다양한 종자에 대한 발아에 따른 유용성분 및 생리활성의 변화에 대한 연구가 활발히 진행되 고 있으나 주요 활성물질의 함랑을 증대시키기 위한 조건의 설정과 관련한 연구는 아직 부족한 실정이다.

일반적으로 곡물의 발아 과정에서 $\mathrm{GABA}$ 는 그 함량이 증가하며(20), 다양한 생리활성을 가지고 있어 기능성 식품 소재로 많이 이용된다(21,22). GABA는 식품 중에 널리 분 포하는 비단백태 아미노산으로 야채, 과일, 녹차, 곡물류 등에 존재하고, 인체에서는 중추신경계 신경전달물질로 작 용하며, glutamate decarboxylase(GAD)의 탈탄산 작용에 의 해 glutamic acid로부터 전환된다(23). 혈압상승 억제, 혈중 cholesterol 및 중성지방의 증가 억제, 뇌의 혈류개선, 비만 방지, 시력증진 작용 이외에 신경의 흥분을 억제하고, 긴장 을 완화시켜 불안감이나 스트레스를 억제하는 등의 많은 약리적 효과가 있다(24). 따라서 식품 중에서 GABA의 생성 량을 증대시키기 위한 방법들이 연구되고 있는데, 현미발 아 또는 혐기적 처리, 급격한 온도변화, 기계적 자극 등의 환경 변화 시 그 함량이 급격하게 증가되는 것으로 보고되 어 있다. GAD와 GABA는 미생물과 동물세포에 이르기까 지 널리 발견되고 있으며 특히 쌀, 콩, 김치의 발효식품에서 분리한 유산균이 고농도의 $\mathrm{GABA}$ 를 생산하는 것으로 알려 져 있다(25).

보리는 $\mathrm{Ca}$ 함량이 높아서 발아 시 현미보다 $\mathrm{GABA}$ 의 생성 효율이 더 높은 것으로 알려져 있으나, 곡물에서 $\mathrm{GABA}$ 의 함량 증가와 관련한 연구는 주로 현미를 이용하고 있어 보리의 GABA 함량에 대한 연구는 미미한 실정이다 (4). 이에 본 연구에서는 전처리 방법을 달리한 후 발아시킨 보리 추출물의 이화학적 특성, 항산화활성 및 tyrosinase 저해활성을 분석함으로써 발아 보리의 GABA 함량 증가와 생리활성 강화를 위한 방안으로 전처리 조건을 확립하기 위한 기초 자료를 확보하고자 하였다.

\section{재료 및 방법}

\section{실험재료 및 시료의 제조}

발아를 위한 보리는 전통시장에서 당해 연도에 생산하여
건조된 국내산 겉보리를 구입하여 사용하였다. 보리 무게 대비 $30 \%$ 의 물을 가하여 상온에서 4 시간 정도 예비 불림한 후 $50^{\circ} \mathrm{C}$ 에서 1 시간 동안 열처리 한 보리(HKW)와 가볍게 세척한 후 보리가 완전히 잠기도록 하여 4 시간 동안 불림 처리 한 보리(KW), 전처리를 전혀 거치치 않은 건조된 보리 (CO)로 시료를 달리하였다. 불림시간 설정은 예비실험으로 보리가 물을 최대로 흡수하는 시점을 확인하기 위하여 1시 간 간격으로 확인한 결과 4시간 후 최대로 흡수하여 불림시 간을 4시간으로 설정하였으며, 발아시간 설정 문헌조사를 통하여 시료 채취 간격을 선정하였다. 각 실험군 별 보리 $40 \mathrm{~g}$ 을 자동급수가 되는 콩나물 재배기(SC-9000A, Sinchang INC, Osan, Korea)에 넣어서 초기 12시간 까지는 연속으로 급수하고, 그 이후부터는 20 분마다 1 분간 급수하면서 발아 시켰다. 35 시간까지 발아시키면서 5 시간 간격으로 시료를 취하였다.

\section{추출물의 제조}

발아 시간에 따라 시료를 취하여 $-70^{\circ} \mathrm{C}$ 에서 보관하였다 가 모두 함께 동결건조 하였다. 동결건조 된 각각의 시료는 분쇄기로 분쇄한 후 무게대비 10 배의 $70^{\circ} \mathrm{C}$ 정제수를 가한 다음 2 분간 진탕 혼합하고 $70^{\circ} \mathrm{C}$ water bath에서 추출액이 모두 잠기게 하여 3 시간 동안 추출한 후 여과지로 여과한 여액을 시료로 사용하였다. 항산화활성 평가를 위한 시료 는 이를 농도별로 다시 희석하여 사용하였다. 일부 실험에 서는 추출여액을 다시 동결건조 한 후 3 차 증류수를 사용하 여 농도로 조절하여 사용하였다.

\section{총 페놀화합물 및 플라보노이드의 정량}

총 폴리페놀의 함량은 폴리페놀성 물질인 phosphomolybdic acid와 반응하여 청색을 나타내는 원리로 Folin-Denis법(26) 에 따라 시료액 $1 \mathrm{~mL}$ 에 $2 \mathrm{M}$ Folin-Ciocalteau 시약(SigmaAldrich Co., St. Louis, MO, USA) $0.5 \mathrm{~mL}$ 를 넣고 3 분 후 $10 \% \mathrm{Na}_{2} \mathrm{CO}_{3}$ 용액 $0.5 \mathrm{~mL}$ 씩을 혼합하여 실온의 암실에서 1 시간 정치한 다음 분광광도계(Libra S 35, Biochrom Ltd., Cambridge, England)를 이용하여 $760 \mathrm{~nm}$ 에서 흡광도를 측 정하였다. 시료와 동일한 방법으로 표준물질인 gallic acid(Sigma-Aldrich Co.)를 농도별로 분석하여 얻은 검량선 으로 부터 총 폴리페놀 함량을 계산하였다.

총 플라보노이드의 함량은 시료액 $1 \mathrm{~mL}$ 에 $10 \%$ aluminum nitrate $0.1 \mathrm{~mL}, 1 \mathrm{M}$ potassium acetate $0.1 \mathrm{~mL}$ 및 $80 \%$ 에탄올 $3.8 \mathrm{~mL}$ 를 차례로 가한 후 혼합하여 실온의 암실에서 40 분간 정치한 다음 분광광도계를 이용하여 $415 \mathrm{~nm}$ 에서 흡광도를 측정하였다. Quercetin(Sigma-Aldrich Co.)을 표준물질로 하여 얻은 검량선으로 부터 총 플라보노이드 함량을 계산하였다.

\section{$\mathrm{GABA}$ 정량}

$\mathrm{GABA}$ 의 정량을 위해 효소분석 방법을 이용하여 발아된 
보리를 분쇄한 후 10 배의 물을 가하여 진탕 추출한 다음 여과한 여액 $1 \mathrm{~mL}$ 에 $70 \mathrm{mM} \mathrm{LaCl} 31 \mathrm{~mL}$ 를 가하여 15 분 동안 잘 섞어준 후 $4,000 \mathrm{rpm}$ 에서 5 분간 원심분리 하였다. 상등액 $400 \mu \mathrm{L}$ 를 취하여 $0.1 \mathrm{M} \mathrm{KOH} 160 \mu \mathrm{L}$ 를 미리 넣어둔 centrifuge tube에 넣어 5 분간 교반하였다. 다시 $4,000 \mathrm{rpm}$ 에 서 5 분간 원심 분리한 상등액 $50 \mu \mathrm{L}$ 에 $0.5 \mathrm{M} \mathrm{K} \mathrm{P}_{2} \mathrm{O}_{7}$ 완충용 액(pH 8.6) $50 \mu \mathrm{L}, 4 \mathrm{mM} \mathrm{NADP} 150 \mu \mathrm{L}$ 를 첨가한 후, 2.0 unit/mL GABase $50 \mu \mathrm{L}$ 를 혼합하여 $340 \mathrm{~nm}$ 에서 흡광도를 측정하였으며(initial A), $20 \mathrm{mM}$ a-ketoglutarate를 $50 \mu \mathrm{L}$ 넣 고 $37^{\circ} \mathrm{C}$ 에서 3 시간 동안 반응시킨 후 $340 \mathrm{~nm}$ 에서 흡광도를 측정(final A)하였다. 농도별 GABA(Sigma-Aldrich Co.)를 동일한 조건에서 분석한 표준검량곡선에 측정된 흡광도 (final A-initial A)를 대입하여 생성된 GABA 함량을 산출하 였다.

\section{항산화 활성 측정}

조건별 시료의 항산화 활성은 1,1-diphenyl-2- picrylhydrazyl (DPPH) 및 2,2-azinobis-(3-ethylbenzo- thiazoline-6-sulphonate) (ABTS) 라디칼 소거활성을 통하여 측정하였다. $\mathrm{DPPH}$ 라디 칼 소거활성은 $\mathrm{DPPH}$ 에 대한 전자공여 활성으로 나타낸 것으로 Blois(27)의 방법을 응용하여 측정하였다. 즉, $\mathrm{DPPH}$ 용액 $(5 \mathrm{mg} / 100 \mathrm{~mL}$ methanol) $80 \mu \mathrm{L}$ 와 시료 $120 \mu \mathrm{L}$ 를 혼합한 다음 실온에서 20 분간 반응시킨 후 분광광도계를 이용하여 $525 \mathrm{~nm}$ 에서 흡광도를 측정하여 시료 무첨가구에 대한 시료 첨가구의 흡광도비로 계산하여 \%로 나타내었다.

$\mathrm{ABTS}$ 라디칼 소거활성은 $\operatorname{Re}$ 등(28)의 방법에 따라 7 $\mathrm{mM}$ 의 ABTS 용액에 potassium persulfate를 $2.4 \mathrm{mM}$ 이 되도 록 용해시킨 다음 암실에서 12-16시간 동안 반응시킨 후 $415 \mathrm{~nm}$ 에서 흡광도가 1.5 가 되도록 증류수로 조정한 ABTS 용액을 사용하였다. ABTS 용액 $100 \mu \mathrm{L}$ 에 시료액 $100 \mu \mathrm{L}$ 를 혼합하고 실온에서 5 분간 반응시킨 다음 분광광도계를 이 용하여 $415 \mathrm{~nm}$ 에서 흡광도를 측정하여 시료 무첨가구에 대한 시료 첨가구의 흡광도비로 계산하여 \%로 나타내었다.

\section{통계처리}

모든 실험은 3회 이상 반복하여 실시하였으며 실험으로 부터 얻은 결과는 SPSS statistics 18(IBM, Armonk, NY, USA) 통계 package를 이용하여 분석하였다. 결과는 평균 표준편차로 표시하였고, 일원배치 분산분석을 한 후 $\mathrm{p}<0.05$ 수준에서 Duncan's multiple range test를 시행하였다.

\section{결과 및 고찰}

발아 시간에 따른 총 페놀화합물과 플라보노이드의 함량

전처리 방법을 달리한 보리를 35시간까지 발아시키면서 5 시간 간격으로 시료를 취해 총 페놀화합물과 플라보노이
드의 함량을 분석한 결과는 각각 Fig. 1 및 2와 같다. 모든 시료에서 총 페놀화합물의 함량은 발아 전 27.59-30.63 $\mathrm{mg} / 100 \mathrm{~g}$ 이던 것이 발아 5시간 후에 $17.73-19.00 \mathrm{mg} / 100$ $\mathrm{g}$ 으로 유의적으로 감소한 후 불규칙한 증감을 보이면서 변화하다가 최종 발아 35시간 후에는 20.96-23.29 mg/100 $\mathrm{g}$ 의 범위로 발아 전에 비해 유의적으로 낮은 함량이었다. 발아 5시간에 총 페놀화합물의 함량은 발아 전에 비해 61.5-64.4\%로 감소한 후 $\mathrm{HKW}$ 는 발아 20-25시간에, $\mathrm{KW}$ 와 $\mathrm{CO}$ 는 발아 $30-35$ 시간에 유의적으로 그 함량이 높았다.

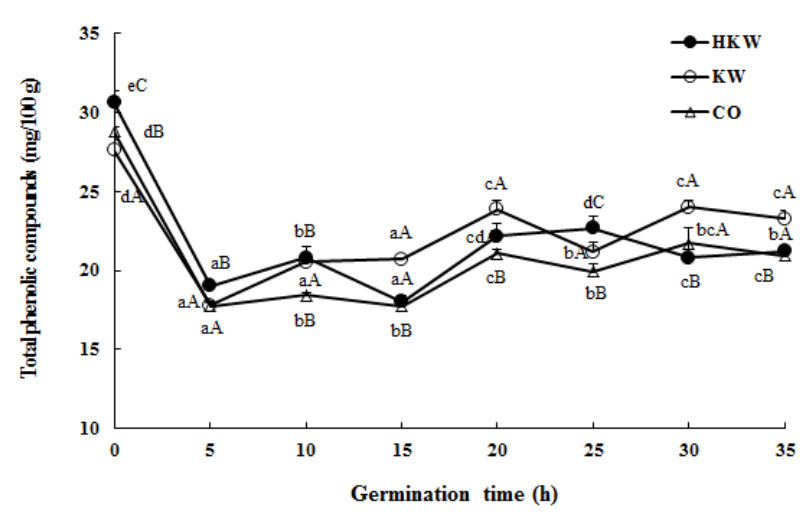

Fig. 1. Total phenolic compounds contents of barely with different pre-treatment method and germination time.

All values are mean $\pm \mathrm{SD}(\mathrm{n}=3)$.

$\mathrm{HKW}$, stored at $50^{\circ} \mathrm{C}$ for $1 \mathrm{~h}$ after keep in water for $4 \mathrm{~h}$ at room temperature before germination; $\mathrm{KW}$, keep in water for $4 \mathrm{~h}$ at room temperature before germination; $\mathrm{CO}$, control, not pre-treated.

${ }^{a e}$ Means with different superscripts within the same pre-treatment method are significantly different $(p<0.05)$ by Duncan's multiple range test.

${ }^{A-C}$ Means with different superscripts within the same germination time are significantly different $(\mathrm{p}<0.05)$ by Duncan's multiple range test.

전처리 방법을 달리한 보리의 발아기간 동안 플라보노이 드 함량도 발아 전 시료에서 유의적으로 가장 높아 $3.53-4.63 \mathrm{mg} / 100 \mathrm{~g}$ 이었고, 발아 5시간 후에 1.69-1.87 $\mathrm{mg} / 100 \mathrm{~g}$ 으로 유의적으로 감소한 후 발아 10 시간에는 다시 증가하는 경향을 보인 다음부터는 불규칙한 증감을 반복하 여 최종 발아 35 시간에는 $2.13-2.42 \mathrm{mg} / 100 \mathrm{~g}$ 의 범위였다. 발아 전에는 $\mathrm{KW}$ 시료에 비해 $\mathrm{HKW}$ 와 $\mathrm{CO}$ 시료에서 유의적 으로 함량이 더 높았으나 발아 35시간 후에는 세 시료간의 유의적인 차이가 없었다.

곡류에 함유되어 있는 항산화 물질 중 polyphenolic 화합 물들은 우수한 항산화력을 가지는데, 이는 free radical을 안정화시킬 수 있는 phenolic ring의 존재 때문이며, 그 구조 에 따라 특정 플라보노이드는 항산화 및 항균성 등 다양한 생리활성을 갖고 있는 것으로 보고되고 있다(30).

Woo 등(31)은 황금찰수수의 항산화 성분인 폴리페놀, 플라보노이드, 탄닌 등은 grain 보다 껍질층 인 bran과 hull에 다량으로 존재하며, 껍질층에 있는 수용성 성분들이 살수 에 의해 씻겨나가 불규칙한 증감을 반복하는 페놀 함량과 플라보노이드 함량에 영향을 준다고 보고하였다. 또한 곡 
류가 발아 시 유리형 및 결합형 기능성분이 변화하는데 세포벽의 결합형 폴리페놀 및 플라보노이드는 일반적으로 셀룰로스, 펙틴, 다당류 등의 세포벽 성분과 공유결합을 하고 있으며, 발아 초기 결합형 폴리페놀의 일부가 추출이 가능한 유리형 세포벽의 결합형 폴리페놀 및 플라보노이드 는 일반적으로 셀룰로스, 펙틴, 다당류 등의 세포벽 성분과 공유결합을 하고 있으며, 발아 초기 결합형 폴리페놀의 일 부가 추출이 가능한 유리형 폴리페놀로 변화하여 총 폴리페 놀함량이 증가한다고 보고하였다(32). 본 연구에서 발아전 보리보다 발아 5 시간 후 그 함량이 급격히 감소한 결과는 발아과정 중 수분을 흡수하면서 상대적인 건물량에 의한 차이가 발생하였으며, 발아시간에 따른 변화는 발아과정 중에 효소의 작용, 분해 등으로 인해 불규칙하게 변화된 것으로 추정된다.

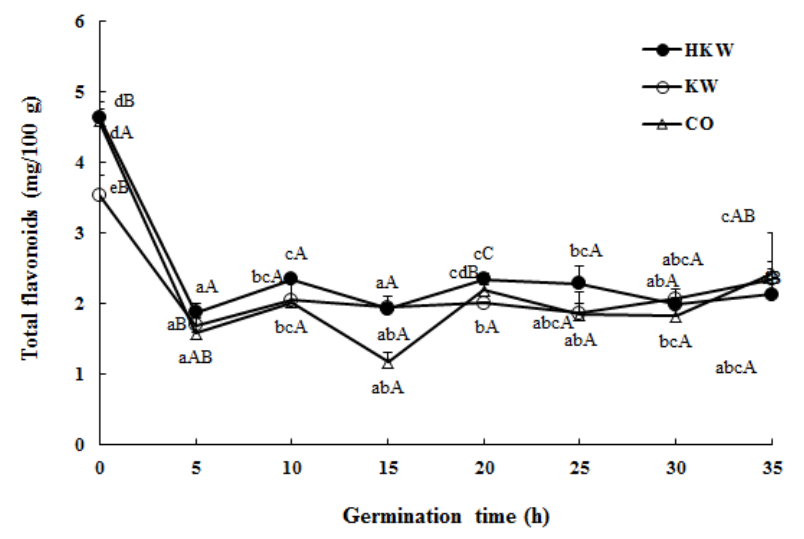

Fig. 2. Total flavonoids contents of barely with different pre-treatment method and germination time.

All values are mean $\pm \mathrm{SD}(\mathrm{n}=3)$.

$\mathrm{HKW}$, stored at $50^{\circ} \mathrm{C}$ for $1 \mathrm{~h}$ after keep in water for $4 \mathrm{~h}$ at room temperature before germination; $\mathrm{KW}$, keep in water for $4 \mathrm{~h}$ at room temperature before germination; $\mathrm{CO}$, control, not pre-treated.

${ }^{a t}$ Means with different superscripts within the same pre-treatment method are significantly different $(\mathrm{p}<0.05)$ by Duncan's multiple range test.

${ }^{A-C}$ Means with different superscripts within the same germination time are significantly different $(\mathrm{p}<0.05)$ by Duncan's multiple range test.

\section{발아 시간에 따른 GABA 함량변화}

전처리 조건과 발아시간별 보리의 GABA 함량을 분석한 결과는 Table 3 과 같이 모든 시료에서 발아시간의 경과와 더불어 함량이 증가하는 경향을 보이다가 다시 감소하였는 데, 전처리 조건에 따라 그 경향은 다소 상이하였다. 즉, 보리에 물을 충분히 흡수시킨 후 $50^{\circ} \mathrm{C}$ 에서 1 시간 동안 열처 리 한 보리를 사용한 $\mathrm{HKW}$ 시료의 경우 발아 25 시간까지 $\mathrm{GABA}$ 의 함량은 증가하여 $22.25 \mathrm{mg} / 100 \mathrm{~g}$ 으로 최고값을 보인 후 감소하였다. 전처리를 전혀 하지 않은 건조된 $\mathrm{CO}$ 시료의 경우 3 가지 시료 중 $\mathrm{GABA}$ 의 함량이 가장 낮았으며, 발아 30 시간에 $12.31 \mathrm{mg} / 100 \mathrm{~g}$ 으로 최고값을 보인 후 그 함량이 다시 감소하였다. 불림처리만을 거친 후 발아시킨 $\mathrm{KW}$ 시료의 경우도 발아 30 시간에 $16.15 \mathrm{mg} / 100 \mathrm{~g}$ 으로 최고 값을 보인 이후 그 함량이 다시 감소하였다.
Table 3. GABA contents of barely with different pre-treatment method and germination time

\begin{tabular}{cccc} 
& \multicolumn{3}{c}{ Pre-treatment method } \\
\hline $\begin{array}{c}\text { Germination time } \\
\text { (h) }\end{array}$ & HKW & $\mathrm{KW}$ & $\mathrm{CO}$ \\
\cline { 2 - 4 } & $\left.12.48 \pm 0.69^{2 / \mathrm{a} 3) \mathrm{C} 4}\right)$ & $5.45 \pm 1.22^{\mathrm{aB}}$ & $1.72 \pm 0.34^{\mathrm{aA}}$ \\
\hline 0 & $13.87 \pm 1.44^{\mathrm{abC}}$ & $7.89 \pm 0.53^{\mathrm{bB}}$ & $4.31 \pm 1.03^{\mathrm{bA}}$ \\
5 & $15.32 \pm 0.53^{\mathrm{bCC}}$ & $10.71 \pm 2.30^{\mathrm{cB}}$ & $8.84 \pm 1.55^{\mathrm{cA}}$ \\
10 & $17.77 \pm 0.72^{\mathrm{deC}}$ & $11.33 \pm 0.40^{\mathrm{cB}}$ & $9.24 \pm 1.22^{\mathrm{cdA}}$ \\
15 & $19.55 \pm 0.24^{\mathrm{eC}}$ & $12.02 \pm 1.55^{\mathrm{cB}}$ & $10.55 \pm 0.49^{\mathrm{cdeA}}$ \\
20 & $22.25 \pm 0.20^{\mathrm{fC}}$ & $14.44 \pm 0.53^{\mathrm{dB}}$ & $10.90 \pm 0.01^{\mathrm{deA}}$ \\
25 & $17.78 \pm 1.44^{\mathrm{deB}}$ & $16.15 \pm 1.11^{\mathrm{dB}}$ & $12.31 \pm 1.92^{\mathrm{eA}}$ \\
30 & $16.51 \pm 2.08^{\mathrm{cdC}}$ & $15.01 \pm 1.05^{\mathrm{dB}}$ & $11.52 \pm 0.34^{\mathrm{eA}}$ \\
35 &
\end{tabular}

${ }^{1)} \mathrm{HKW}$, stored at $50^{\circ} \mathrm{C}$ for $1 \mathrm{~h}$ after keep in water for $4 \mathrm{~h}$ at room temperature before germination; KW, keep in water for $4 \mathrm{~h}$ at room temperature before germination; $\mathrm{CO}$, control, not pre-treated.

${ }^{2)}$ All values are mean $\pm \mathrm{SD}(\mathrm{n}=3)$

${ }^{3) a-1}$ Means with different superscripts within the same pre-treatment method are significantly different $(\mathrm{p}<0.05)$ by Duncan's multiple range test.

4)A-C Means with different superscripts within the same germination time are significantly different $(\mathrm{p}<0.05)$ by Duncan's multiple range test.

$\mathrm{GABA}$ 의 생성은 수분, 온도, 칼슘제제, 키토산 제제, glutamate, 기계적 자극, 산소결핍 등의 외부적 환경요인을 조절하여 증가시키는 방법들이 보고되어져 있다(33) 본 연 구의 예비실험 결과 $\mathrm{GABA}$ 의 함량은 전처리 과정만을 거친 후에도 그 함량에 차이가 있어 발아 전(0시간) 불림과 열처 리를 거친 $\mathrm{HKW}$ 시료에서 $12.48 \mathrm{mg} / 100 \mathrm{~g}$ 으로 불림 과정만 한 $\mathrm{KW}$ 시료에 비해서 약 2.3 배, 전처리를 하지 않은 $\mathrm{CO}$ 시료에 비해서는 약 7.3배 더 높은 함량이었다. $\mathrm{HKW}$ 시료 에서는 $\mathrm{GABA}$ 함량이 최고치에 이르는 시간이 25 시간이므 로 30시간이 소요된 다른 시료에 비해 더 짧고 그 함량도 더 높아 발아 전 충분히 흡수시키고 효소작용에 적절한 온도와 시간을 제공함으로써 $\mathrm{GABA}$ 함량을 보다 효율적으 로 증가시킬 수 있음을 확인하였다.

$\mathrm{Oh}$ 등(34)은 보리의 $\mathrm{GABA}$ 함량이 발아에 의해서 2 배 증가하였다고 하였으며, Choi 등(20)은 침지 전 현미의 $\mathrm{GABA}$ 함량은 $1.80 \mathrm{mg} / 100 \mathrm{~g}$ 이던 것이 $40^{\circ} \mathrm{C}$ 에서 침지시킬 경우 침지시간이 경과함에 따라 계속 증가하여 8시간 후 $3.33 \mathrm{mg} / 100 \mathrm{~g}$ 으로 가장 크게 증가하였으며, $50^{\circ} \mathrm{C}$ 침지 시에 는 약 2 시간까지는 급격히 증가하였으나 그 후 약간 감소하 여 평형을 이루는 경향을 나타내었고 $10^{\circ} \mathrm{C}$ 와 $25^{\circ} \mathrm{C}$ 침지 시에는 8 시간 경과 후에도 각각 $2.12 \mathrm{mg} / 100 \mathrm{~g}$ 과 2.49 $\mathrm{mg} / 100 \mathrm{~g}$ 으로 별다른 증가를 나타내지 않았다고 보고 한 바 있다. 이처럼 발아 곡물의 GABA 함량은 발아시간 보다 는 온도에 더 크게 영향을 받는 것으로 보고(7)되어 있는데 본 연구의 결과와 같이 발아 온도를 동일하게 하였을 때는 전처리 방법이 발아 중 $\mathrm{GABA}$ 함량에 직접적인 영향을 미침을 확인할 수 있었다. 


\section{발아 시간에 따른 항산화 활성}

전처리 조건과 발아 시간을 달리한 보리 물 추출물의 항산화 활성을 $\mathrm{DPPH}$ 및 $\mathrm{ABTS}$ 라디칼 소거활성을 통해 평가한 결과는 각각 Table 4 및 5와 같다. 발아 전 시료들의 $\mathrm{DPPH}$ 라디칼 소거활성은(Table 4) 64.72-68.72\%로 통계적 인 유의차가 없었으나 발아 5시간에 활성이 급격히 감소하 여 52.48-58.49\%로 가장 낮았다가 다시 발아 시간이 경과함 에 따라 점진적으로 활성이 증가하였다. $\mathrm{HKW}$ 는 20시간과 25 시간 발아 시료에서 각각 $73.72 \%$ 와 $77.40 \%$ 로 두 시료 간의 유의차 없이 활성이 가장 높았고, $\mathrm{KW}$ 시료는 25 시간 발아 시 가장 활성이 높았다.

Table 4. DPPH radical scavenging activity of barely with different pre-treatment method and germination time

$(\%)$

\begin{tabular}{cccc}
\hline \multirow{2}{*}{$\begin{array}{c}\text { Germination time } \\
\text { (h) }\end{array}$} & \multicolumn{3}{c}{ Pre-treatment method } \\
\cline { 2 - 4 } & $\mathrm{HKW}$ & $\mathrm{KW}$ & $\mathrm{CO}$ \\
\hline 0 & $66.44 \pm 2.68^{2)(\mathrm{cc}) \mathrm{dA} 4)}$ & $64.72 \pm 2.72^{\mathrm{cdA}}$ & $68.72 \pm 2.21^{\mathrm{dA}}$ \\
5 & $58.49 \pm 1.49^{\mathrm{aB}}$ & $52.48 \pm 1.08^{\mathrm{aA}}$ & $52.56 \pm 1.57^{\mathrm{aA}}$ \\
10 & $60.33 \pm 0.95^{\mathrm{aAA}}$ & $57.62 \pm 2.25^{\mathrm{bA}}$ & $56.98 \pm 2.28^{\mathrm{bA}}$ \\
15 & $64.21 \pm 3.46^{\mathrm{bcdB}}$ & $61.32 \pm 2.90^{\mathrm{bcAB}}$ & $57.51 \pm 2.18^{\mathrm{bA}}$ \\
20 & $73.72 \pm 2.42^{\mathrm{eB}}$ & $70.27 \pm 3.66^{6 \mathrm{~B}}$ & $62.50 \pm 2.72^{\mathrm{cA}}$ \\
25 & $77.40 \pm 0.50^{\mathrm{eB}}$ & $75.78 \pm 1.78^{\mathrm{fB}}$ & $65.02 \pm 1.44^{\mathrm{cdA}}$ \\
30 & $62.47 \pm 2.74^{\mathrm{abcA}}$ & $69.14 \pm 3.84^{\mathrm{deB}}$ & $62.75 \pm 2.39^{\mathrm{cA}}$ \\
35 & $67.40 \pm 1.61^{\mathrm{dAB}}$ & $71.91 \pm 3.16^{\mathrm{eAB}}$ & $65.45 \pm 2.50^{\mathrm{cdA}}$ \\
\hline
\end{tabular}

${ }^{1)} \mathrm{HKW}$, stored at $50^{\circ} \mathrm{C}$ for $1 \mathrm{~h}$ after keep in water for $4 \mathrm{~h}$ at room temperature before germination; $\mathrm{KW}$, keep in water for $4 \mathrm{~h}$ at room temperature before germination; $\mathrm{CO}$, control, not pre-treated.

${ }^{2)}$ All values are mean $\pm \mathrm{SD}(\mathrm{n}=3)$.

3)- Means with different superscripts within the same pre-treatment method are significantly different $(\mathrm{p}<0.05)$ by Duncan's multiple range test.

${ }_{4 A-C}$ Means with different superscripts within the same germination time are significantly different $(\mathrm{p}<0.05)$ by Duncan's multiple range test.

발아 시간별 보리 추출물의 $\mathrm{ABTS}$ 라디칼 소거활성 (Table 5)은 발아 전 시료에서 유의적으로 활성이 가장 높아 $85.72-88.10 \%$ 의 범위였으며, $\mathrm{DPPH}$ 라디칼 소거활성과 동 일한 경향으로 발아 5시간에 가장 낮아 46.28-58.15\%의 범 위였다. 그 이후부터 발아 30 시간 까지는 점진적으로 활성 이 증가하여 발아 30 시간에 $\mathrm{ABTS}$ 라디칼 소거활성은 $71.40-80.25 \%$ 로 발아 기간 중 가장 활성이 높았으며, 그 이후에는 60.26-74.37\%의 범위로 다시 활성이 감소하였다.

$\mathrm{ABTS}$ 라디칼 소거활성은 $\mathrm{DPPH}$ 라디칼 소거활성과 상 관관계가 높은데, $\mathrm{DPPH}$ 라디칼 소거활성은 유리 라디칼을 $\mathrm{ABTS}$ 라디칼 소거능은 양이온 라디칼을 소거한다는 점에 서 차이가 있으며, 항산화성 물질의 정도에 따라 라디칼과 결합하여 제거하는 능력에도 차이가 있다(35). 본 연구의 결과에서 발아 보리 추출물은 DPPH 라디칼 보다는 ABTS 라디칼을 소거하는 능력이 더 우수하여 양이온 라디칼 소거
에 더 유리하게 작용할 것으로 생각된다.

$\operatorname{Kim}$ 등(36)의 연구에서 일품벼를 발아시켰을 때 항산화 력은 발아 4일 차에서 최대값을 보인 후 감소하는 결과를 보였는데 본 연구에서 발아 초기에 비해 발아 5일에 항산화 활성이 감소는 총 페놀화합물과 플라보노이드 화합물의 영향으로 추측되며 DPPH 라디칼 소거활성은 발아 25시간, $\mathrm{ABTS}$ 라디칼 소거활성은 발아 30시간에 활성이 가장 좋았 고 그 이후 활성이 점차 감소하여 유사한 경향이었다. 이는 발아 후 일정기간 증가하였다가 감소하는 $\mathrm{GABA}$ 함량과 또는 항산화 성분인 비타민 $\mathrm{E}$ 및 $\mathrm{\gamma}$-oryzanol의 함량의 종합 적인 변화에 따른 것으로 추정되는데, 비타민 $\mathrm{E}$ 와 $\mathrm{\gamma}$ -oryzanol은 발아하기 전 생리적 대사물질로 합성되었다가 발아가 진행되면서 식물의 성장과 생리대사 작용에 관여하 여 성장촉진제와 생리대사 상승 작용에 활용되면서 그 함량 이 감소한다(37).

Table 5. ABTS radical scavenging activity of barely with different pre-treatment method and germination time

$(\%)$

\begin{tabular}{cccc}
\hline \multirow{2}{*}{$\begin{array}{c}\text { Germination time } \\
\text { (h) }\end{array}$} & \multicolumn{3}{c}{ Pre-treatment method $^{1)}$} \\
\cline { 2 - 4 } & $\mathrm{HKW}$ & $\mathrm{KW}$ & $\mathrm{CO}$ \\
\hline 0 & $88.10 \pm 0.13^{2 \mathrm{bb3}) \mathrm{BA})}$ & $85.72 \pm 1.76^{\mathrm{fA}}$ & $87.46 \pm 0.29^{\mathrm{fAB}}$ \\
5 & $54.57 \pm 0.70^{\mathrm{aB}}$ & $46.28 \pm 2.04^{\mathrm{AA}}$ & $58.15 \pm 0.59^{\mathrm{aC}}$ \\
10 & $68.72 \pm 0.29^{\mathrm{eC}}$ & $51.18 \pm 1.00^{\mathrm{bA}}$ & $58.20 \pm 0.80^{\mathrm{aB}}$ \\
15 & $66.31 \pm 0.49^{\mathrm{dC}}$ & $52.57 \pm 1.48^{\mathrm{bA}}$ & $60.97 \pm 0.71^{\mathrm{bB}}$ \\
20 & $64.36 \pm 0.58^{\mathrm{CB}}$ & $58.40 \pm 0.42^{\mathrm{cA}}$ & $63.67 \pm 1.03^{\mathrm{cB}}$ \\
25 & $77.76 \pm 0.74^{\mathrm{fB}}$ & $71.54 \pm 0.89^{\mathrm{dA}}$ & $70.97 \pm 0.51^{\mathrm{eA}}$ \\
30 & $80.25 \pm 0.83^{\mathrm{gC}}$ & $76.36 \pm 0.93^{\mathrm{eB}}$ & $71.40 \pm 0.78^{\mathrm{eA}}$ \\
35 & $60.26 \pm 1.32^{\mathrm{bA}}$ & $74.37 \pm 1.00^{\mathrm{eC}}$ & $65.46 \pm 1.22^{\mathrm{dB}}$ \\
\hline
\end{tabular}

${ }^{11} \mathrm{HKW}$, stored at $50^{\circ} \mathrm{C}$ for $1 \mathrm{~h}$ after keep in water for $4 \mathrm{~h}$ at room temperature before germination; $\mathrm{KW}$, keep in water for $4 \mathrm{~h}$ at room temperature before germination; $\mathrm{CO}$, control, not pre-treated.

${ }^{2)}$ All values are mean $\pm \mathrm{SD}(\mathrm{n}=3)$.

${ }^{3) \text { ah }}$ Means with different superscripts within the same pre-treatment method are significantly different $(p<0.05)$ by Duncan's multiple range test.

${ }^{4 A-C}$ Means with different superscripts within the same germination time are significantly different $(p<0.05)$ by Duncan's multiple range test.

\section{요 약}

전처리 방법이 발아보리의 $\mathrm{GABA}$ 를 중심으로 한 주요성 분과 항산화 및 미백활성에 미치는 영향을 확인하고자 보리 무게 대비 $30 \%$ 의 물을 가하여 4 시간 침지시킨 후 $50{ }^{\circ} \mathrm{C}$ 에서 1 시간 열처리한 시료 $(\mathrm{HKW})$ 와 보리가 완전히 물에 잠기도 록 하여 4시간 동안 침지시킨 시료 $(\mathrm{KW})$ 및 전처리를 거치 지 않은 대조군(CO)으로 구분하여 35시간까지 발아시키면 서 5시간 간격으로 시료를 취하였다. 발아기간 동안 $\mathrm{HKE}$ 시료에서 총 페놀화합물(18.02-30.63 mg/100 g)과 플라보노 
이드 $(1.87-4.63 \mathrm{mg} / 100 \mathrm{~g})$ 의 함량이 타 시료에 비해 높았고, $\mathrm{GABA}$ 함량은 전처리를 거친 후 발아시킨 $\mathrm{HKW}$ 와 $\mathrm{KW}$ 시료가 전처리를 거치지 않은 $\mathrm{CO}$ 시료보다 높았다. DPPH 및 $\mathrm{ABTS}$ 라디칼 소거활성은 모든 시료에서 각각 52.48-77.40\%와 46.28-88.10\%의 범위였고, 20-30시간 발아 시킨 $\mathrm{HKW}$ 시료에서 활성이 높았다. 이상의 결과를 종합하 여 볼 때 보리는 발아를 시키기 전과 후, 전처리 유무에 따라 활성의 차이를 보였는데, 항산화 활성과 GABA 함량 을 증가시키기 위해서는 침지 후 열처리과정을 거치는 전처 리 방법이 적합하며 적정 발아 시간은 20-25시간으로 판단 된다.

\section{References}

1. Kim HY, Hwang IG, Kim TM, Park DS, Kim JH, Kim DJ, Lee JS, Jeong HS (2011) Antioxidant and angiotensin converting enzyme I inhibitory activity on different parts of germinated rough rice. J Korean Soc Food Sci Nutr, 40, 775-780

2. Kim YS, Lee YT, Seong HM (1999) Physicochemical properties of starches from waxy and non-waxy hull-less barleys. J Korean Soc Agric Chem Biotechnol, 42, 240-245

3. Ju JI, Lee KS, Min HI, Lee BJ, Kwon BG, Gu JH, Oh MJ (2007) Changes in physicochemical characteristics of green barley according to days after heading. Korean J Crop Sci, 52, 36-44

4. Cho MZ (1995) Studies on the variation of diet fiber content according to pearling ratio of barley. J Korean Home Econ Assoc, 33, 181-186

5. Jung EY, Yum CA, Kim SK, Jang MS (1987) The chemical composition of pearled, cutted, and pressed barleys. Korean J Food Sci Technol, 19, 290-294

6. Oh HJ, Lee SR (1996) Physiological function in vitro of $\beta$-glucan isolated from barley. Korean J Food Sci Technol, 28, 689-695

7. Lee YR, Kim JY, Woo KS, Hwang IG, Kim KH, Kim KJ, Kim JH, Jeong HS (2007) Changes in the chemical and functional components of Korean rough rice before and after germination. Food Sci Biotechnol, 16, 1006-1010

8. Paucar-Menacho LM, Berhow MA, Gontijo Mandarino JM, Chang YK, de Mejia EG (2010) Effect of time and temperature on bioactive compounds in germinated Brazilian soybean cultivar BRS 258. Food Res Int, 43, 1856-1865
9. Cha MN, Jun HI, Song GS, Kim YS (2012) The effects of germination conditions on GABA and the nutritional components of barley. Korean J Food Sci Technol, 44, 41-47

10. Bartnick M, Szafranska I (1987) Changes in phytate content and phytase activity during the germination of some cereals. J Cereal Sci, 5, 23-28

11. Kim HY, Hwang IG, Kim TM, Kim DJ, Park DS, Kim JH, Lee JS, Jeong HS (2010) Antiproliferation effects of ethanol and water extracts from germinated rough rice. J Korean Soc Food Sci Nutr, 39, 1107-1112

12. Kim HY, Hwang IG, Joung EM, Kim TM, Kim DJ, Park DS, Lee JS, Jeong HS (2010) Antiproliferation effects of germinated-Korean rough rice extract on human cancer cells. J Korean Soc Food Sci Nutr, 39, 325-330

13. Yu AR, Park HY, Hong HD, Min JY, Choi HD (2015) Changes in the nutritional components and immuneenhancing effect of glycoprotein extract from pre- and post-germinated barley seeds. Korean J Food Sci Technol, 47, 511-516

14. Sim GS, Lee DJ, Kim JH, Lee BC, Ahn SK, Choe TB, Pyo HB (2006) Sprouted black rice oligopeptide induces expression of hyaluronan synthase in $\mathrm{HaCaT}$ keratinocytes and improves skin elasticity. J Soc Cosmet Sci Korea, 32, 7-15

15. Kim ES Jeong NH (2014) Anti-inflammatory effect of germinated mung bean and hairdye applications. $\mathrm{J}$ of Korean Oil Chem Soc, 31, 23-30

16. Ko JY, Song SB, Lee JS, Kang JR, Seo MC, Oh BG, Kwak DY, NAM MH, Jeong HS, Woo KS (2011) Changes in chemical components of foxtail millet, proso millet, and sorghum with germination. J Korean Soc Food Sci Nutr, 40, 1128-1135

17. Lee EH, Kim CJ (2008) Nutritional changes of buckwheat during germination. Korean J Food Culture, 23, 121-129

18. Ghung DS, Kim HK (1998) Changes of protein and lipid composition during germination of Perilla frutescens seeds. Korean J Life Sci, 8, 318-325

19. Kim JS, Kim JG, Kim WJ (2004) Changes in isoflavone and oligosaccharides of soybeans during germination. Korean J Food Sci Technol, 36, 294-298

20. Choi HD, Park YK, Kim YS, Chung CH, Park YS (2004) Effect of pretreatment conditions on $\gamma$-aminobutyric acid content of brown rice and germinated brown rice. Korean J Food Sci Technol, 36, 761-764

21. Bown AW, Shelp BJ (1997) The metabolism and functions of $\gamma^{-}$-aminobutyric acid. Plant Physiol, 115, 
$1-5$

22. Zhang H, Yao HY, Chen F, Wang X (2007) Purification and characterization of glutamate decarboxylase from rice germ. Food Chem, 101, 1670-1676

23. Oh SH (2007) Effects and applications of germinated brown rice with enhanced levels of GABA. Food Science and Industry, 40, 41-46

24. Lim SD, Kim KS (2009) Effects and utilization of GABA. Korean J Dairy Sci Technol, 27, 45-51

25. DS Kim (2010) Study on the condition of fermentation in lactic acid bacteria for the production of $\mathrm{\gamma}$ -aminobutyric acid. MS Thesis, Hannam University, Korea, p 56

26. Folin O, Denis W (1912) On phosphotungsticphosphmolybdic compounds as color reagents. J Biol Chem, 12, 239-243

27. Blois MS (1958) Antioxidant determinations by the use of a stable free radical. Nature, 181, 1199-1200

28. Re R, pellegrini N, Proteggente A, Pannala A, Yang M, Rice-Evans C (1999) Antioxidant activity applying an improved ABTS radical cation decolorization assay. Free Radical Biol Med, 26, 1231-1237

29. Hwang CR, Seo WT, Bae WY, Kang MJ, Shin JH (2014) Physicochemical characteristics and biological activities of Artemisia Argyi H. Korean J Life Sci, 24, 377-385

30. Middleton E, Kandaswami C (1994) Potential healthpromoting properties of citrus flavonoids. Food Technol, 48, 115-119

31. Woo KS, Seo MC, Kang JR, Ko JY, Song SB, Lee JS, Oh BG, Park GD, Lee YH, Nam MH, Jeong HS (2010) Antioxidant compounds and antioxidant activities of the methanolic extracts from milling fractions of sorghum (Sorghum bicolor L. Moench). J Korean Soc Food Sci Nutr, 39, 1695-1699

32. Cho YU, Chang JY, Chang HC (2007) Production of $\gamma$-aminobutyric acid (GABA) by Lactobacillus buchneri isolated from kimchi and its neuroprotective effect on neuronal cells. J Microbiol Biotechnol, 17, 104-109

33. Oh SH, Moon YJ, Oh CH (2003) r-Aminobutyric acid (GABA) content of selected uncooked foods. Nutraceuticals Food, 8, 75-78

34. Kim MY, Jang GY, Oh NS, Baek SY, Kim KH, Kim KM, Kim HS, Lee JS, Jeong HS (2017) Change in free and bound of bioactive compound profiles of adzuki bean with germination. J Korean Soc Food Sci Nutr, 46, 973-943

35. Wang MF, Li J, Rangarajan M, Shao Y, Lavoie EJ, Huang TC, Ho CT (1998) Antioxidative phenolic compounds from sage (Salivia officinalis). J Agric Food Chem, 46, 4869-4873

36. Kim HY, Lee SH, Hwang IG, Kim TM, Park DS, Kim JH, Kim DJ, Lee JS, Jeong HS (2012) Antioxidant activity and anticancer effects of rough rice (Oryza sativa $\mathrm{L}$.) by germination periods. J Korean Soc Food Sci Nutr, 41, 14-19

37. Kim HY, Hwang IG, Kim TM, Park DS, Kim JH, Kim DJ, Lee YR, Lee JS, Jeong HS (2011) Changes in chemical composition of rough rice (Oryza sativa L.) according to germination period. J Korean Soc Food Sci Nutr, 40, 1265-1270 